\title{
GOKHRU (TRIBULUS TERRESTRIS AND PEDALIUM MUREX): MEDICINAL IMPORTANCE OF CHOTA GOKHRU AND BADA GOKHRU IN AYURVEDA AND MODERN SCIENCE
}

\author{
SHAILJA CHOUDHARY, HEMLATA KAURAV, GITIKA CHAUDHARY*
}

Shuddhi Ayurveda, Jeena Sikho Lifecare Pvt. Ltd. Zirakpur 140603, Punjab, India. Email: shuddhi.research@jeenasikho.co.in

Received: 09 March 2021, Revised and Accepted: 23 April 2021

\begin{abstract}
Tribulus terrestris and Pedalium murex are the two popular herbal plants originated from a very famous Ayurvedic plant named Gokshuru. These plants are well known for their medicinal importance. In Ayurveda, T. terrestris is known as laghu gokhshuru and P. murex is known as brihat gokshuru. The fruits of T. terrestris plant are slightly astringent in taste while the fruits of $P$. murex are somewhat sweeter in taste. The fruits are used to treat various diseases such as urinary disorder adrenal stone. In this current paper, we have discussed the pharmacological, Ayurvedic and folk uses of these plants in every region of the world. From various reported studies, it was found that the T. terrestris plant carries much medicinal importance while the P. murex fruits is only used as a substitute or as an adulterant of the T. terrestris plant. It was found that the T. terrestris plant is mainly used to cure urinogenital disorders and kidney disorders such as renal and gall bladder stone. On the other hand, the $P$. murex plant carries aphrodisiac property and mainly used to cure sexual disorders like infertility, erectile dysfunctioning in both male and females. It was also found that these plants have some similar phytochemical constituents which possess aphrodisiac, anti-inflammatory, demulcent, diuretic properties, and also used to cure other diseases such as cough, asthma, cardiac disease, vesical calculi, and gall bladder stone. These plants are known for major therapeutic properties such as anti-ulcerative, antiurolithic, anticancer, aphrodisiac, analgesic, stomachic, anti-hypertensive, diuretic, urinary anti-infective, cardio tonic, antibacterial, anti-inflammatory, nephroprotective, antispasmodic, anthelmintic, and anti-carcinogenic.
\end{abstract}

Keywords: Tribulus terrestris, Pedalium murex, Gokhru, Aphrodisiac, Rasapanchak, Ayurveda.

(C) 2021 The Authors. Published by Innovare Academic Sciences Pvt Ltd. This is an open access article under the CC BY license (http://creativecommons.org/ licenses/by/4.0/) DOI: http://dx.doi.org/10.22159/ajpcr.2021v14i6.41366. Journal homepage: https://innovareacademics.in/journals/index.php/ajpcr

\section{INTRODUCTION}

Tribulus genus belongs to the family Zygophyllaceae commonly known as "small caltrop," "Chota Gokhru," "puncture vine," goat head, devil's thorn, and "Gokhshura" in Sanskrit [1,2]. The Latin meaning of the word Tribulus is "three pointed caltrops" suggested for the three pronged fruit of Tribulus terrestris fruit with projecting spikes [2] It is the most important herbal plant popularly known for its folk uses in various parts of the world to treat different ailments [3]. There are almost 20 species of this plant out of which three main species Tribulus cistoides, T. terrestris, and Tribulus alatus are found in India (Fig. 1) [4]. It is a significant medicinal plant used traditionally and therapeutically to treat various diseases. It is mainly found in the tropical and subtropical regions of the world. Conventionally, it is used to enhance the hormonal production in both male and females [5]. The ripened dry fruit which is called as Khar-e Khasak Khurd is used to treat dysuria and gonorrhea disease in Unani medicinal system [6]. Furostanol and spirostanol are the main saponin components found in this plant that is known for its therapeutic properties [7]. T. terrestris is mainly used to treat urinary and kidney disorders. Furthermore, it consists of other medicinal properties such as diuretic, antiurolithic, immunomodulatory, anticancer, aphrodisiac, analgesic, stomachic, anti-hypertensive, diuretic, lithontriptic, urinary anti-infective, cardiotonic, antibacterial, anti-inflammatory, antispasmodic, antihelmintic, larvicidal, and anti-carcinogenic [8]. The other type of caltrop is Pedalium murex (Fig. 2) commonly known as "large caltrop," "Gokhru or gokhar" and "gaja-daunstraka, gokshura or tittagokshura" in Sanskrit [9]. It belongs to the family Pedaliaceae. This plant as a whole or individual parts are used to treat diseases like common cold, cough and is used as an antiseptic [10]. Conventionally, it is used to treat sexual and other reproductive disorders such as impotency gonorrhea, infertility, and premature ejaculation as it contains diosgenin and vanillin constituents which are responsible for the aphrodisiac property $[11,12]$. It is used in Unani and Ayurvedic medicinal system as a cooling agent and improves appetite, asthma, inflammation, piles, leprosy, heart diseases, cough, and vesicular calculi. It also contains pharmacological properties such as anti-oxidant, anti-ulcerogenic, nephroprotective, hypolipidemic, aphrodisiac, antimicrobial, and insecticidal properties [13]. Taxonomical classification and vernacular name are given in Tables 1 and 2.

\section{BOTANICAL DESCRIPTION}

\section{T. terrestris linn}

Tribulus terresteris is a small prostate, branched, annual herb that belongs to the family Zygophyllaceae [22]. The height of this plant reaches up to $90 \mathrm{~cm}$ in length. The roots of the plant are fibrous, narrow, light brown, 4-5 inches long, fragmented, astringent, and sweet in taste. The leaves are opposite somewhat round shaped, pinnately compound, short petiole containing 5-6 pairs of leaflets that are 6-12 $\mathrm{mm}$ in length [23]. The flowers are silky, hermaphrodite, solitary axillary consists of 5 broad yellow petals that are $4-10 \mathrm{~mm}$ in width rises from axils of leaves [15]. The fruits of this plant are spinous, glabrous, five cornered, hairy and covered by greenish yellow colored sharp thorns, minutely muricate, woody cocci containing two pairs of sharp spines usually one pair longer than the other [24].

\section{P. murex}

P. murex commonly known as large caltrop and Bara Gokhru is branched, succulent fleshy, and annual glandular herbal plant that reaches up to the height of 30-50 cm. The leaves are simple, reticulate, ovoid, alternate, and opposite and are 3.2-5.3 cm in length and 1-2.7 $\mathrm{cm}$ in breadth [25]. The roots of the plant are white and have sweet fragrance. Flowers are round, solitary about $2.5-3 \mathrm{~cm}$ long, bright yellow and axillary with short pedicle consist of 5 calyxes with gamopetalous corolla, 5 lobes, 4 stamens, didynamous, 5 celled ovules, 2 lobed style, and stigma [18,26]. The corolla tube consists of glabrescent hairs. The fruits of this plant are four angled, fleshy containing conical horizontal trichrome from the angles [27]. The stem of the plant is stiffed. The leaves and stem of the plant when soaked into cold water turns into tasteless pale thick paste which carry great medicinal property. 


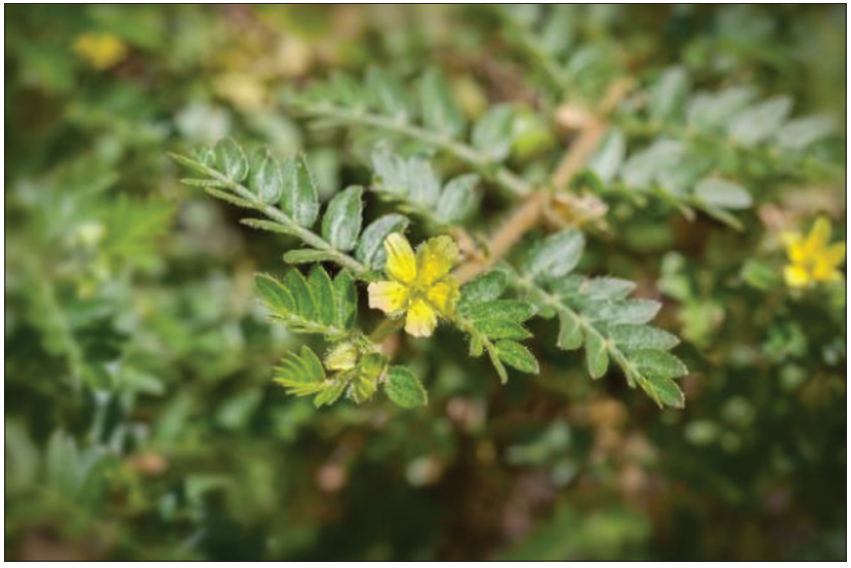

Fig. 1: Tribulus terrestris

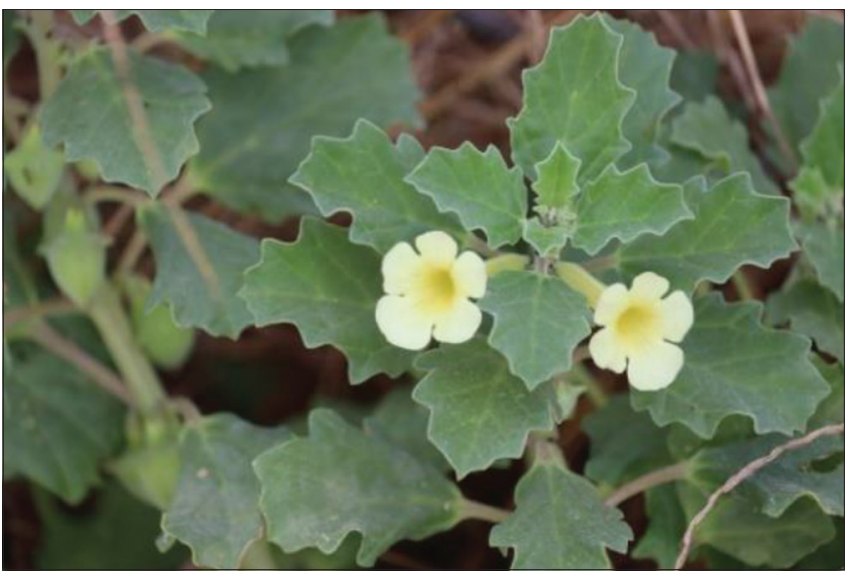

Fig. 2: Pedalium murex

\section{GEOGRAPHICAL DISTRIBUTION}

\section{T. terrestris}

T. terrestris is a native of Mediterranean region and is mainly found in tropical and subtropical region in the universe. It is widely distributed in the countries like Southern USA, Mexico, South Africa, Middle east, Pakistan, Sri Lanka, Vietnam, Sothern Europe, Spain, Bulgaria, India and China $[3,28,29]$. The best soil considers for its growth is sandy soil but can also grow in loamy and clayey soil. It is mainly grown in waste land as a weed like in road side, dry and grazing land. It is commonly found at an altitude of $5400 \mathrm{~m}$ to 11000 feet in Kashmir. In India, it is mainly found in Bihar, Andhra Pradesh, Tamil Nadu, North-west states and the Gangetic plains [30].

\section{P. murex}

It is found mainly in the tropical and subtropical regions of the world. It is mostly seen in countries like south Africa, Sri Lanka, India, Mexico and Pakistan. It is distributed in the western and coastal regions of India and is mainly considered as weed which grows in waste and dry places [31]. In India, it is widely scattered in states like Tamil Nadu, Rajasthan, Punjab, Gujarat, Delhi, and Deccan peninsula [32,33].

\section{PHYTOCHEMICALS CONSTITUENTS OF GOKSHURA}

\section{T. terrestris}

T. terrestris plant contain number of chemical constituents named as steroids, saponins, flavonoids, alkaloids, vitamins, tannins, unsaturated acids, resins, nitrate potassium, aspartic acid, and glutamic acid [9]. This plant is the richest source of calcium $4.21 \%$, crude protein $12.06 \%$, ether extract $2.61 \%$, total ash $16.72 \%$, phosphorus $0.25 \%$, and total digestive nutrients $55.63 \%$ [34]. The steroidal saponins, diosgenin,
Table 1: Taxonomical classifications of Tribulus terrestris [14,15]

\begin{tabular}{lll}
\hline Taxonomical rank & Taxon & \\
\hline Taxonomy & Tribulus terrestris & Pedalium murex \\
Domain & Eukaryota & Eukaryota \\
Kingdom & Plantae & Plantae \\
Phyllum & Spermatophyta & Spermatophyta \\
Sub-phyllum & Angiospermae & Angiospermae \\
Class & Dicotyledonae & Magnoliopsida \\
Order & Geraniales & Lamiales \\
Family & Zygophyllaceae & Pedaliaceae \\
Genus & Tribulus & Pedalium \\
Species & Terrestris & murex \\
Common name & Chota Gokhru & Bara Gokhru \\
\hline
\end{tabular}

Table 2: Vernacular names of Tribulus terrestris Linn and Pedalium murex

\begin{tabular}{|c|c|c|}
\hline Language & Tribulus terrestris & Pedalium murex [16] \\
\hline English & $\begin{array}{l}\text { Calotrops fruits [17], calthrops, } \\
\text { small caltrops [18,19], Land } \\
\text { caltrops, puncture vine [13] }\end{array}$ & Large Caltrops \\
\hline Hindi & $\begin{array}{l}\text { Gokhru }[20,21], \text { Gokshri, } \\
\text { Burrokhur }\end{array}$ & $\begin{array}{l}\text { Bara Gokhru, Fareed } \\
\text { buti, Dakshini } \\
\text { Gokshur }\end{array}$ \\
\hline Sanskrit & $\begin{array}{l}\text { Shvadanstra, Traikantaka, } \\
\text { Gokshuru, Bahkanataka }\end{array}$ & Brihata Gokshur \\
\hline Arabic & $\begin{array}{l}\text { Khask, Kharakhusk, } \\
\text { Zufratulajooz [14], } \\
\text { Hamasulameer, Kohuj }\end{array}$ & kHasake-Kabir \\
\hline Urdu & Gokharu & Gokharu \\
\hline Marathi & $\begin{array}{l}\text { Sarate, Gokharu, Lahanogokharu, } \\
\text { Sarala, Sharatte, Lahangokhru }\end{array}$ & Mothe Gokharu \\
\hline Bengali & $\begin{array}{l}\text { Gokshura, Gokhri, Gokhru, } \\
\text { Gokhura, Gokshra, Gokhuri }\end{array}$ & Bad gokhru \\
\hline Gujarati & $\begin{array}{l}\text { Nahannagokharu, Mithagokhru, } \\
\text { Betagokhru }\end{array}$ & $\begin{array}{l}\text { Oobha Gokhru, } \\
\text { Mhyota Gokhru, } \\
\text { Kadawa Gokhru }\end{array}$ \\
\hline Punjab & Gokhrudesi, Lotak, Kurkundai & Gokru Kalan \\
\hline
\end{tabular}

gitogenin, chlorogenin, ruscogenin, and flavonoids are considered as the most significant phytochemicals extracted from the TT plant consisting of various biological properties [15].

\section{Steroidal saponins}

The saponin content is mostly found in leaves and roots and is absent in stem and seeds. The total 108 saponin components are reported to be isolated from TT plant out of which 58 are spirostane saponins and 50 are furostane saponins. The most considerable saponins found in the TT plant are spirostanol and furostanol. Protodioscin and protogracillin are the two steroidal saponins that are considered to carry great biological properties [35]. The other two new steroidal glycosides extracted from the aerial parts are neohecogenin glucoside of tribulosin, six-glycoside quercetin, eight glycosides of iso-hamnein, and four glycosides of kaempferol [36].

\section{Flavonoids}

The leaves and fruit part of TT plant are a source of flavonoids components named as kaempferol, kaempferol-3-glucoside, kaempferol-3-rutinoside, and tribuloside. The derivatives of quercetin component extracted are quercetin, isoquercitrin, rutin, quercetin-3-oagent, quercetin-3-gentr, quercetin-3-0-rha-gent, and quercetin-3-0gent-7-0-glu are flavonoids derived from its parent structure $[24,37,38]$. Isorhamnetin, isorhamnetin-3-0-glu, isorhamnetin-3-0-gent, isorhamnetin-3-0-rutinoside, isorhamnetin-3-0-gentr, isorhamnetin3,7-di-0-glu, isorhamnetin-3-0-p-coumarylglu, isorhamnetin-3-0gent-7-0-glu, isorhamnetin-3-0-gentr-7-0-glu with isorhamnetin as the 
parent structure $[39,40]$. Kaempferol, kaempferol-3-0-glu, kaempferol3-0-gent, kaempferol-3-0-rutinoside, kaempferol-3-0-gent-7-0-glu, and tribuloside with kaempferol as the parent structure [41,42].

\section{Alkaloids}

The alkaloids extracted from the leaf, fruit and roots of TT plant are tribulusamide $\mathrm{C}$, tribulusterine, tribulusin $\mathrm{A}$, harmine, harman, harmmol, tribulusimide $\mathrm{C}$, terrestriamide, $N$-trans-coumaroyltyramine, $\mathrm{N}$-trans-caffeoylyramine, and terrestribisamide [43-45].

\section{Other}

The fruit part of the plant also contains essential oils, fixed oil, nitrates gitogenin rhamnose rutin, sterols, reducing sugar, ruscogenin, neogitogenin, hecogenin, and campestrol. The root part of the plant possesses phytosterols, amino acids, campesterol, stigma sterol, $\beta$-sitosterol, trillin, and furostanol of glycoside. The other organic acids extracted from the TT plant are succinic acid, benzoic acid [46], vanillic acid, 2-methyl benzoic acid, ferulic acid, palmitic acid monoglyceride, docosanoic acid [47], and tribulus acid [48]. Alanine and threonine are the two major amino acids extracted from TT plant. Furthermore, it contains coumarin, emodin, physcion [49], uracil nucleic acid, and 4-ketopinoresinol [50] (Fig. 3) represents the chemical structures of some major phytochemical constituents of TT plant.

\section{P. murex}

The main chemical components present in the P. murex plant are diosegenin and vanillin. There are several others components which were reported to be present in the different parts of the plant [36]. The chemicals constituents found in the P. murex plant include phytosterols, tannins saponins, carbohydrates, reducing sugars, xanthoproteins, saponins, alkaloids, triterpenoids, flavonoids, phenolic compound, alkaloids, resins, flavonoids, saponins, proteins, steroids [47,51], stigma sterol, flavonoids, alkaloids, glycosides, stable oil, resins, aromatic oil, triterpenoid, carbohydrates, amino acids, and phenols [52].

\section{Flavonoids}

Flavonoids are reported as the main component extracted from the stem flowers, roots, and leaves of the P. murex plant. It is known for its pharmacological and physiological property $[8,53,54]$. Pedalitin, diosmetin, dinatin, quercetin, kaempferol, luteolin, and 20,40,50-trihytlroxy-5,7-dimethoxyflavone are some of the flavonoids components extracted from the P. murex plant $[52,55,56]$.

\section{Saponins}

Sitosterol and Diosegenin are the two main phytochemicals extracted from the fruit of the P. murex plant. They are responsible for the production of sexual hormones, corticosteroids, and oral contraceptives [34,57-59].

\section{Terpenoids}

Lupeol acetate has been reported to have significant biological property and is used as a chemo preventive agent to treat various diseases $[58,60,61]$. Urosolic acid is also present as an active constituent in fruit part of the plant which is considered as pentacyclictriterpenoid. It is mainly used in cosmetics as an additive and also acts as an antitumor agent $[62,63]$.

\section{Phenols}

The phenolic components of the P. murex plant are vanillic acid, luteolin. Vanillic acid is mainly used as an antioxidant agent and acts against cardiac disorder whereas luteol act as anti-inflammatory, anti-allergy, and anticancer agent [64-67]. The other acids reported are nonacosane, triacontanol acid, and amino acids such as threonine, asparatic acid, glutamic acid, and histidine which were extracted from the fruits of the P. murex plant $[64,68,69]$ (Fig. 4) represents the chemical structures of some major phytochemical constituents of P. murex plant.

\section{FOLK USES OF GOKSHURA}

\section{T. terrestris}

T. terrestris is commonly known as chota gokhru in Indian culture. It is used in Indian medicinal system for 5000 years [12]. Traditionally, it is used as a medicine in Indian Ayurveda from ancient time to boost hormonal production in both the sexes, that is, in men and women [70]. The fruit part of this plant has been used to treat sexual problems, eye problem, edema, abdominal distension, and leucorrhoea in the traditional Chinese medicinal system. Furthermore, the roots and fruit part of the plant have been used for the treatment of other sexual diseases such as impotency, premature ejaculation, menorrhagia, piles, renal and vesical calculi rheumatism, headaches, and dizziness [71]. In ancient time, it was used to treat diuretic antiseptic, aphrodisiac, and anti-inflammatory diseases according to Indian Ayurveda system. The extract of the T. terrestris plant when mixed with honey it acts as surimi and applied over the eyes to treat eye disease. Furthermore, it is used to treat oral cavities by doing gargling with the decoction of the plant to treat toothache, gums, and stomatitis. It is not only used in the Indian medicinal system but also used by Unani medicinal system in powder form to treat female infertility, dysuria, and micturition problem. It is also used in the paste form to treat wound and skin inflammation when mixed with honey. It is effective against back pain and for treating gall bladder stone [72]. Furthermore, it is used to treat female sexual disorders, periods problem, burning sensation, heart diseases, kidney disease, and skin inflammation. In turkey, it is used as a traditional medicine to treat colic pains, hypertension, and diabetes [73]. Bulgaria people used this plant as a sex enhancer and to treat sexual problems such as infertility and impotency. T. terrestris plant is also useful in hormonal balancing system and provides relief from pre-menstrual tension and menopause which results in optimum function [1]

\section{P. murex}

Whole plant

P. murex plant is of great medicinal importance and has been used in traditional medicinal system. It is consumed either as a whole plant or as individual parts. It is also used as a blood purifier and to treat gall bladder stones. It was studied that the tribal people use dry leaves of $P$. murex, kalmishora, and Acacia nilotica in crushed form to treat urinary bladder problem [35]. In Pakistan, P. murex plant was detected to possess diuretic property [74]. In Rayalaseema, it is used for treating urinary calculi and renal problems [73]. This plant is used for the treatment of diarrhea, headache, dysentery, cough and common cold, stomach ache, intestinal infections by Ayurveda doctors and vadhyas in district Haridwar and Uttarakhand state of India $[75,76]$. This plant is utilized by tribal people of Rajasthan and Saperas community to treat sexual problems and male infertility. It is also utilized in laddu form to treat leucorrhoea in females where the plant is crushed with the root of chlorophyllum [77].

\section{Fruit}

Conventionally, the fruit of this plant is utilized in the powder form to cure reproductive disorders when mixed with Cleome viscose [78]. Fruit part is also used to treat diuretic disease in goats and cattle's. The infusion of fruits is useful to treat urinary problems [79-81]. The fruit in the powder form when mixed with the roots of Capparis sepiaris cure GIT diseases when taken orally which acts as a cooling agent [76]. It is also reported to have aphrodisiac, antispasmodic and demulcent property [82].

Root

Conventionally, the roots of the plant are used to treat nocturnal emission and leucorrhoea. It is also used to calm down body temperature when taken in powder form with water [83]. Root paste possesses aphrodisiac activity.

Seed

The seed of the P. murex plant is utilized in laddu form to treat joint pain and lumbago [82]. 


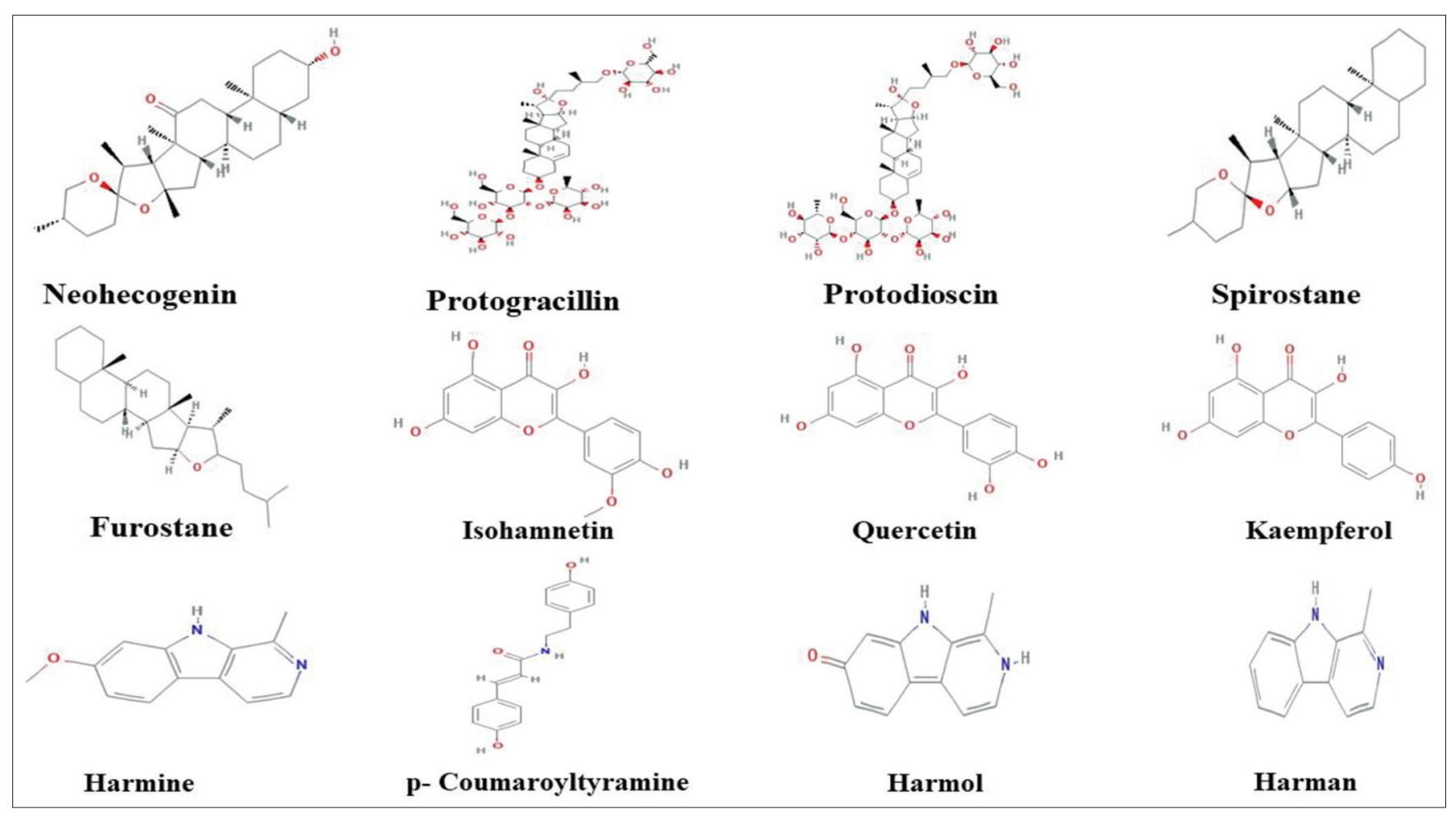

Fig. 3: Chemical structures of some major phytochemical structure of TT plant

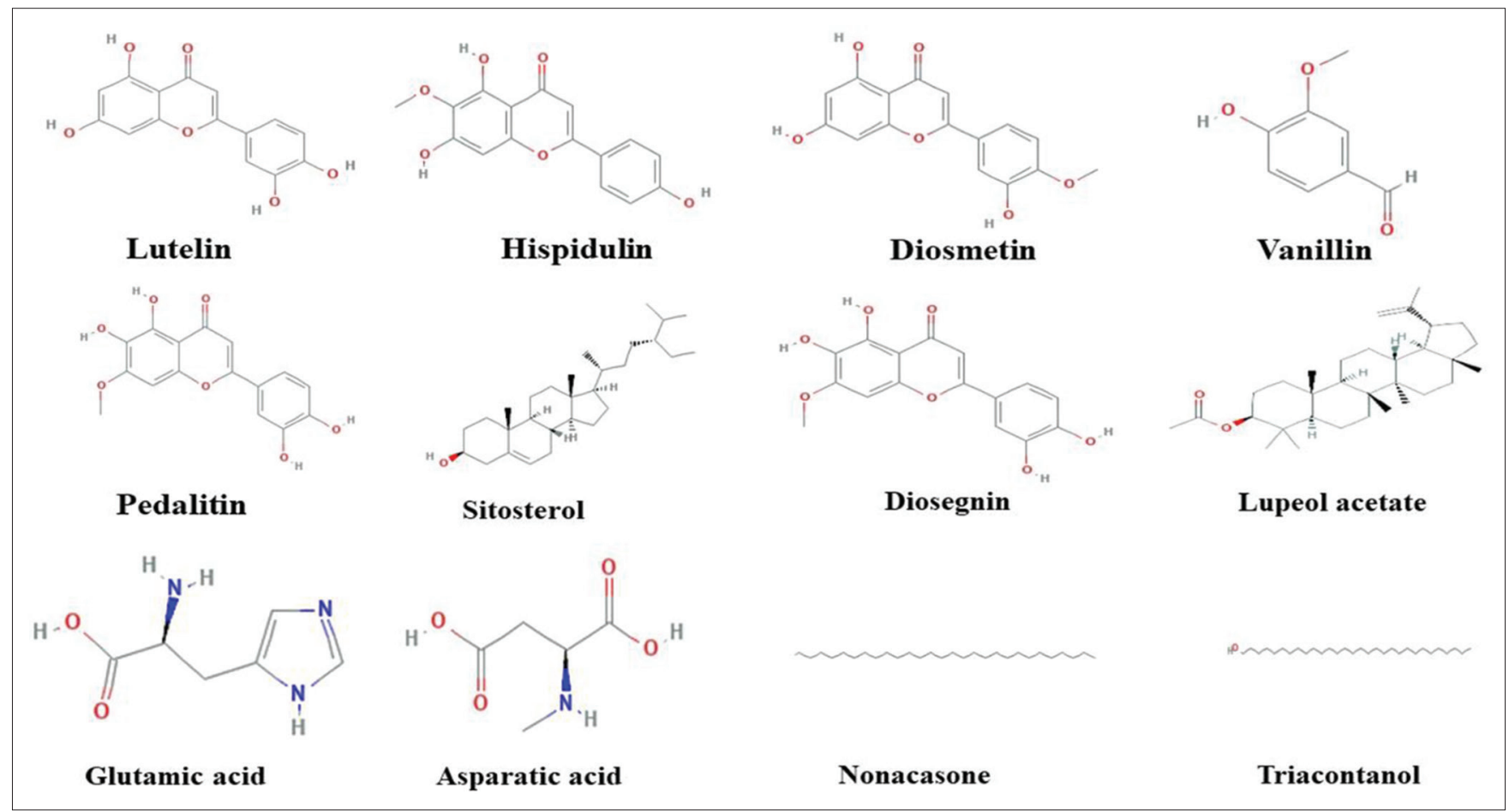

Fig. 4: Chemical structures of some major phytochemicals of Pedalium murex plant

\section{GOKHRU IN AYURVEDA}

T. terrestris and P. murex plants are known as Gokshura in Ayurveda and are considered as well- known herbal plants used in the Indian medicinal system (Ayurveda). It is a component of dashmoola (group of ten medicinal plants) where root part is used to treat various ailments. This drug is well defined by Charaka Samhita, Sushrut Samhita, Astanga Hridaya (Brahatrayi). In madanapala Nighantu, it is specified that fruit of the plant possess aphrodisiac property and roots are used in dashmoola (anti-inflammatory activities). In Samhitas and Nighantus, the two types of Gokshura found are Brihat Gokshura ( $P$. murex Linn) and Laghu Gokshura (T. terrestris Linn) [84]. In Ayurvedic formulations, the fruit part of Laghu Gokshura is used to treat urinary disorders, impotency, calculus formation and other urinary related infections [85]. Furthermore, the fruit of the P. murex plant is used to treat antispasmodic, aphrodisiac, urinary problem, cough asthma, 
Table 3: Rasapanchak (Properties) of Gokshura (Tribulus terrestris and Pedalium murex) [86]

\begin{tabular}{ll}
\hline Sanskrit/English & Sanskrit/English \\
\hline Virya/Potency & Sheet/cold \\
Guna/Physical property & Guru/Heavy, Snigdha/ \\
Vipak/Metabolic property & Madhura/sweet \\
Rasa/Taste & Katu/Atringent, Madhura/sweet \\
\hline
\end{tabular}

diuretic, demulcent, gall bladder stones, cardiac, and skin diseases. Table 3 represents the Ayurvedic properties of the Gokshuru plant.

\section{Ayurvedic Action of Gokshura (Karma) [87]}

Vatahara (वातहरा): Calms vata (maintain circulatory system).

Kaphahara (कफ हरा): It maintains the body fluid, control growth and strengthen the body.

Pittahara (पतिहरा): It is used to maintain digestive system.

Vrishya (वृषय): It is used to treat sexual diseases.

Brimhana (ब्रम्हिनाना): It is used to increase the body weight.

Mutrala (मुतराला): It is used to treat urinary disorders

Balya (बलया): It enhances the immunity, strength and stamina.

Dipana (दीपना): It promotes digestion by producing digestive heat.

Kesya (कश्या): It improvises the hair quality.

Shothahara (शोथहरा): It is used to decrease swelling or edema.

Vedanasthapana (वेदनास्थपंना): It is used as a painkiller and also possesses anesthetic effect.

\section{Properties of Gokshuru $[88,89]$}

Amavata (आमवात): It is used to treat Rheumatoid arthritis disease. Amlapitta (अमलापति): It is used to treat hyperacidity.

Antravriddhi (अंतरावेरधि): It is used to treat hernia.

Ashmari (अश्मरी): It is effective against renal stone.

Arsha (अर्शा): It is used to cure piles.

Hridroga (हरतिरोगा): It is used to treat cardiac diseases.

Raktapitta (रक्तपत्ति): It is used to treat bleeding disorder.

Shoola (शिल): It act as pain-reliever.

Shotha (शोठा): It is used to cure edema.

Vatarakta (वातरकत): It is used to cure gout.

\section{THERAPEUTIC USES OF GOKSHURA}

\section{Reported therapeutic uses of $T$. terrestris}

Diuretic

The nitrate content present in seeds and fruit part of the TT plant is responsible for diuretic property. Furthermore, the aqueous extract of TT plant contains potassium salt in high concentration [90]. The aqueous extract of the TT plant when given orally to albino rat model, the sodium, and chloride concentration in urine increased. Reported studies showed the diuretic property of the plant which helps in treating kidney disorder patients [17].

\section{Aphrodisiac}

Various reported studies showed that the saponin component of the TT plant mainly protodioscin and protogracillin possess aphrodisiac property [91]. It was examined in albino rat model and was found that the protodioscin component converts testosterone into potent dehydrotestosterone very rapidly which increases the sex desire and also increases the production of RBCs [92]. So is used to treat sexual related diseases such as premature ejaculation, erectile dysfunctioning. and also increase the production of sex hormones [93].

\section{Antiurolithic}

The experimental study was conducted on albino rats to find out the anti-urolithic activity [94]. It was found that the ethanolic extract of TT fruits inhibited the growth of $\mathrm{CaOx}$ crystals and also possess cytoprotective activity [95]. Sodium glycolate and ethylene glycol are responsible for inhibiting the stone formation when tested in various models [96].
Antidiabetic

It was found from the reported studies that the ethanolic extract of the TT plant induces protective effect in streptozotocin-induced diabetic rats by inhibiting the oxidative stress. Furthermore, the saponin content was found to be responsible for lowering the blood sugar level [97].

\section{Analgesic}

The study was conducted in male mice using tail flick test and formalin to find out the analgesic activity of the TT plant. It was found that the methanolic extract of TT plant possesses analgesic activity when given in $100 \mathrm{mg} / \mathrm{kg}$ dosage in male mice [98].

\section{Anthelmintic}

From the reported studies, it was found that the beta sitosterol d-glucoside and tribulosin extracts of the TT plant showed anthelmintic property [99].

\section{Antifungal}

The saponin content extracted from TT plant was studied against fluconazole resistant yeast. It was found that saponin component of TT plant showed in vitro and in vivo antifungal property by destroying the cell membrane, killing fungi or by weakening the virulence of Candida albicans [100].

\section{Reported therapeutic uses of $P$. murex \\ Nephroprotective}

It was reported that the ethanolic extract isolated from the TT fruit possesses great nephroprotective property when compared to standard drug cystone against renal damages produced by cisplatin and cadmium chloride in Wistar rats. The extract was found to lower down the cisplatin-induced nephrotoxicity [101].

Antiulcer

From the reported studies, it was found that the aqueous extract isolated from the $P$. murex leaves possesses antiulcer property when tested in rat model at $200 \mathrm{mg} / \mathrm{kg}$ dosage [102]

\section{Antiproliferative}

Reported studies revealed that the P. murex fruit is found to be a richest source of flavonoids and Vitamin $C$ and acts as an anti-cancer agent by providing protection against cancer stages and by inhibiting oxidative cell damage. Various studies proved that the methanolic extract of the fruit inhibited the significant growth of A549 lung cancer line by lowering the percentage of cell viability [103].

\section{Antioxidant}

Experimental studies have shown that the ethyl acetate component extracted from the P. murex plant have antioxidant property [104]. It was also tested against hepatic rats which was treated with methanolic extract of fruit for 90 days with a dosage of $70 \mathrm{mg} / \mathrm{kg}$. Results showed the decrease in normal level of thiobarbituric acid, diene conjugates, superoxide dismutase, catalase, glutathione peropxidase, and glutathione reductase in blood [105].

\section{Aphrodisiac}

It was found that ethanolic and petroleum ether extract of the P. murex plant possesses aphrodisiac property and treat ethanol induced germ cell damage and infertility when studied in male rat model [106]. It ultimately enhances sperm motility, body weight, mounting behavior, sexual desire, protein, total cholesterol, and testosterone level [107].

\section{Activity against urogenital diseases}

The flavones content present in the P. murex fruit was reported to be effective against urinogenital disorders, for example, dysuria, gonorrhea, and discontinuous of urine flow [108]. 
Anti-inflammatory and analgesic

The anti-inflammatory activity of the $P$. murex plant was proved when tested against Lambda- carrageenan induced paw edema in Wistar albino rats at 200 and $400 \mathrm{mg} / \mathrm{kg}$ dosage. It was found that the ethanolic extract of the fruit of the P. murex plant showed anti-inflammatory and analgesic effect [109].

\section{Insecticidal}

It was reported that the root extract of the $P$. murex plant showed insecticidal activity when tested against Spodoptera litura at third fourth and fifth larval stage. Saponin and tannin component are responsible for the insecticidal property [110]

\section{Antimicrobial}

The reported studies have shown that all the part of the $P$. murex plant possesses antimicrobial activity. It was reported that ethyl acetate isolated from flower of $P$. murex plant was found to be effective against Salmonella typhi, Escherichia coli, Enterococcus faecalis, Bacillus cereus, and Bacillus sabstilis, Lactobacillus. The ethanolic extract isolated from the fruit part was found to be effective against fungal pathogen Trichophyton rubrum and methanolic extract isolated from the leaves and fruit part was found to be effective against bacterial pathogen (Streptococcus pyogenes, E. faecalis, and Klebsiella pneumonia) [111].

\section{Antihyperlipidemic}

It was reported that the ethanolic extract of fruit of the $P$. murex plant was tested against high fat diet fed hypercholesterolemic rats. The decrease in the total cholesterol, trigylcerides, lowdensity lipoprotein - cholesterol, and increased high-density lipoprotein -cholesterol was observed [112].

\section{CONCLUSION}

Conclusively, due to the enrichment in the therapeutic phytochemical constituents, the T. terrestris and P. murex plants are used in various Ayurvedic products and formulations to cure various diseases. From the reported pharmacological studies, it was found that the T. terrestris plant is mainly used to cure urinogenital disorders and kidney disorders such as renal and gall bladder stone. On the other hand, $P$. murex plant has aphrodisiac property and mainly used to cure sexual disorders such as infertility, impotence, premature ejaculation, erectile dysfunctioning in both male and females. Due to the presence of some similar chemical constituents both the plants possesses some similarity in their properties and is used to treat various other diseases such as asthma, cardiac disorder, skin diseases, cough, and also acts as an anti-inflammatory, anticancer, antioxidant, aphrodisiac, antimicrobial, antidiabetic, nephroprotective, and antifungal agent. Both these plants are of significant medicinal value and can be further investigated for developing more Ayurvedic and herbal formulations for wellness of humankind.

\section{AUTHOR CONTRIBUTION}

We declare that this work was done by the authors named in this article and all liabilities pertaining to claims relating to the content of this article will be borne by the authors.

Dr. Gitika Chaudhary drafted the article and contributed in writing ayurvedic view of the article. Dr. Hemlata Kaurav contributed in drafting and writing pharmacological portion of plant. Shailja Choudhary contributed in data collection and writing the paper.

\section{CONFLICT OF INTEREST}

No potential conflict of interest was reported by the authors.

\section{AUTHOR FUNDING}

No any funding for this article writing.

\section{REFERENCES}

1. Samy MN, Bishr MM, Ahmed AA, Sayed HM, Kamel MS. Pharmacognostical studies on flower of Tribulus terrestris L. J Pharmacogn Phytochem 2013;1:18-22.

2. Kostova I, Dinchev D. Saponins in Tribulus terrestris chemistry and bioactivity. Phytochem Rev 2005;4:111-37.

3. Ahmad T, Haque N. Diuretic and lithotriptic potential of Tribulus terrestris (khar khasak) Linn. A comprehensive review. World J Pharm Pharm Sci 2016;7:375-83.

4. Semwal A, Kumar R, Teotia UV, Singh R. Development of quality control parameters for the standardization of bark of Ficus benghalensis Linn. J Acute Dis 2013;2:296-9.

5. Akram M, Asif HM, Akhtar N, Shah PA, Uzair M, Shaheen G, et al. Tribulus terrestris Linn.: A review article. J Med Plants Res 2011;5:3601-5.

6. Evans WC. Trease and Evans Pharmacognosy. $15^{\text {th }}$ ed. Singapore: Sanders Co. Ltd.; 2002.

7. Rajendrabhai DV. Detection of phytochemical and pharmacological properties of crude extracts of Tribulus terrestris collected from tribal regions of Baglan (MS), India. Int J Pharmacogn Phytochem Res 2017;9:508-11

8. Rajashekar V, Rao EU, Srinivas P. Biological activities and medicinal properties of Gokhru (Pedalium murex L.). Asian Pac J Trop Biomed 2012;2:581-5.

9. Patel DK, Laloo D, Kumar R, Hemalatha S. Pedalium murex Linn.: An overview of its phytopharmacological aspects. Asian Pac J Trop Med 2011;4:748-55

10. Devanesan AA, Zipora T, Smilin BA, Deviram G, Thilagar S. Phytochemical and pharmacological status of indigenous medicinal plant Pedalium murex L. a review. Biomed Pharmacother 2018;103:1456-63.

11. Balamurugan G, Muralidharan P, Polapala S. Aphrodisiac activity and curative effects of Pedalium murex (L) against ethanol induced infertility in male rats. Turk J Biol 2010;34:153-63.

12. Chaudhary G, Kaushik N. Phytochemical and pharmacological studies in Pedalium murex L. Phytochem Rev 2017;16:921-34.

13. Dymock W, Warden CJ, Hooper D. In: Paul K, editors. Pharmacographia indica: A History of the Principal Drugs of Vegetable Origin, met with in British India. London: Trench, Trübner and Company, Ltd.; 1893.

14. Muhiuddin GC. Rehnumae Aqaqeer. Vol. 1. New Delhi: Eijaz Publication; 2004. p. 333-8.

15. Ahmed S, Khan AA, Yadav P, Akhtar J, Akram U, Shamim LF. Gokhru (Tribulus terrestris Linn.): Pharmacological actions and therapeutic applications: A review. Int J Herb Med 2020;8:25-9.

16. Chopra RN, Nayar SL, Chopra IC. Glossary of Indian Medicinal Plants. New Delhi: Council of Scientific and Industrial Research; 1956.

17. Mohd J, Akhtar AJ, Abuzer A, Javed A, Ali M, Ennus T. Pharmacological scientific evidence for the promise of Tribulus terrestris. Int Res J Pharm 2012;3:403-6

18. Akhilesh K, Nandini S, Apurva P. Brihata Gokshur (Pedalium murex Linn.): A potent drug for male reproductive system. Int J Res Anal Rev 2016;5:1734-7.

19. Jabbar A, Nazir A, Khalil J, Ansari NI, Janjua KM, Javed F. To compare the effects of Tribulus terristris with hydrochlorothiazide on urine volume and electrolytes. Ann King Edward Med Univ 2015;21:149.

20. Bhandaria M, Ravipati AS, Reddy N, Koyyalamudi SR. J Mol Pharm Org Proc Res 2015;3(3):1-11.

21. Kumar U, Prajapati ND. Agro's Dictionary of Medicinal Plants. India: Agrobios; 2003. p. 216.

22. Gauri M, Javed S. A review of Apium graveo special reference to Unani medicine. Int Arch Integr Med 1906;2:131-6.

23. Chunekar KC. Bhavaprakash nighantu. Varanasi: Chaukhamba Bharati Academy; 1999.

24. Amanullah KZ, Zeenat F, Ahmad W, Firoz S, Naeela A. A comprehensive review on a Unani medicinal plant: Tribulus terrestris Linn. Int J Herb Med 2021;9:23-8.

25. Chaterjee A, Pakrashi S. Annona squamosa in the Treatise of Indian Medicinal Plants. New Delhi: Publication and Information Directorate; 1995. p. 130

26. Hussain SM. Herbal Unani Medicine. Mumbai: Avicenna; 2004

27. Mathew KM. The Flora of Tamil Nadu Karnatic. Polypetalae, Gamopetalae and Monochlamydae. Vol. 1. Tiruchirappalli, India: The Ranipat Herbarium, St. John's College; 1983.

28. Nair NC, Henry AN (eds). Flora of Tamil Nadu, India, Volume 1. Botanical Survey of India, Coimbatore, India.1983.

29. Jenifer S, Laveena DK, Priya S, Singh SJ, Jeyasree J. Antimicrobial screening of Euphorbia hirta L. and Pedalium murex L. A comparative 
study. World J Pharm Pharm Sci 2014;3:1221-6.

30. Warrier PK. Indian Medicinal Plants: A Compendium of 500 Species. Hyderabad, Telangana: Orient Blackswan; 1993.

31. Kirtikar KR, Basu BD. Indian Medicinal Plants. India: Longman; 1935.

32. Amanullah KZ, Zeenat F, Ahmad W, Firoz S, Naeela A. A comprehensive review on a Unani medicinal plant: Tribulus terrestris Linn. Int J Herb Med. 2021;9(1):23-8.

33. Shukla YN, Thakur RS. Heptatriacontan-4-one, tetratriacontanyl octacosanoate and other constituents from Pedalium murex. Phytochemistry 1983;22:973-4.

34. Bhakuni RS, Shukla YN, Thakur RS. Flavonoids and other constituents from Pedalium murex. Phytochemistry 1992;31:2917-8

35. Council OS. The Wealth of India. A Dictionary of Indian Raw Materials and Industrial Products. Vol. 7. N-Pe. The Wealth of India. A Dictionary of Indian Raw Materials and Industrial Products; 1966.

36. Zhu W, Du Y, Meng H, Dong Y, Li L. A review of traditional pharmacological uses, phytochemistry, and pharmacological activities of Tribulus terrestris. Chem Cent J 2017;11:1-6.

37. Rastogi RP, Mehrotra BN, Pastogi RP. Compendium of Indian Medicinal Plants. New Delhi, India: Central Drug Research Institute, Lucknow and Publications and Information Directorate; 1993. p. 10.

38. Qu NN, Yang SS. Extraction and determination of chemical constituents of flavonides in Tribulus terrestris L. J Liaoning Univ Tradit Chin Med 2007;9(3):182-3

39. Saleh NA, Ahmed AA, Abdalla MF. Flavonoid glycosides of Tribulus pentandrus and T. terrestris. Phytochemistry 1982;21:1995-2000.

40. Alavia SH, Yekta MM, Hadjiaghaee R, Ajani Y. Flavonoid glycosides from Tribulus terrestris L. orientalis. Iran J Pharm Sci 2008;4:231-6.

41. Sun W, Gao J, Tu G, Guo Z, Zhang Y. A new steroidal saponin from Tribulus terrestris Linn. Nat Prod Lett 2002;16:243-7.

42. Kostova I, Dinchev D, Rentsch GH, Dimitrov V, Ivanova A. Two new sulfated furostanol saponins from Tribulus terrestris. Z Naturforsch C 2002;57:33-8.

43. Su L, Feng SG, Qiao L, Zhou YZ, Yang RP, Pei YH. Two new steroidal saponins from Tribulus terrestris. J Asian Nat Prod Res 2009;11:38-43.

44. Bhutani SP, Chibber SS, Seshadri TR. Flavonoids of the fruits and leaves of Tribulus terrestris: Constitution of tribuloside. Phytochemistry 1969;8:299-303.

45. Zhang X, Wei N, Huang J, Tan Y, Jin D. A new feruloyl amide derivative from the fruits of Tribulus terrestris. Nat Prod Res 2012;26:1922-5.

46. Wu TS, Shi LS, Kuo SC. Alkaloids and other constituents from Tribulus terrestris. Phytochemistry 1999;50:1411-5.

47. Xu YJ, Xie SX, Zhao HF, Han D, Xu TH, Xu DM. Studies on the chemical constituents from Tribulus terrestris. Acta Pharm Sin 2001;36:750-3.

48. Lv AL, Zhang N, Sun MG, Huang YF, Sun Y, Ma HY, et al. One new cinnamic imide dervative from the fruits of Tribulus terrestris. Nat Prod Res 2008;22:1007-10.

49. Ren YJ, Chen HS, Yang GJ, Zhu H. Isolation and identification of a new derivative of cinnamic amide from Tribulus terrestris. Acta Pharm Sin 1994;29:206.

50. Yi WA, Guang CH, Yuan YU. Chemical constituents of Tribulus terrestris L. J Beijing Univ Chem Technol 2009;36:79.

51. Chen H, Chen Q, Xuan W. A new organic acid from Tribulus terrestris. Acad J Second Mil Med Univ 2004;25(11):1241-2.

52. Wang FX, Sun XG, Wang ZF, Kang LP, Wu KL, Zhao Y, et al. Chemical constituents of Tribulus terrestris L. Plant Med 2016;82:PC45.

53. Subramanian SS, Nair AG. Flavonoids of the leaves of Pedalium murex. Phytochemistry 1972;11(1):464-5.

54. Imran M, Kumar N, Nohri F, Kumar D, Kousar T, Sultan MT, et al. Phytochemical and pharmacological potentials of Pedalium murex Linn and its traditional medicinal uses. J Coastal Life Med 2015;3:737-43.

55. Tapiero H, Tew KD, Ba GN, Mathe G. Polyphenols: Do they play a role in the prevention of human pathologies? Biomed Pharmacother 2002;56:200-7.

56. Valenzuela A, Sanhueza J, Nieto S. Natural antioxidants in functional foods: From food safety to health benefits. Grasas Aceites 2003;54:295-303.

57. Muhamed-Kasim S, Neelakantan S, Raman PV. Chemical components of Indian medicinal plants (Thespesia populnea wood and Calycopteris floribunda flowers). Curr Sci 1975;44(24):888-9.

58. Sharma P, Sarin R. Isolation and characterization of quercetin and kaempferol in vivo and in vitro from Pedalium murex. Int Res J Pharm 2012;3:184-7.

59. Kalyani R, Komal K, Shukla VJ, Prajapati PK. A study to evaluate diosgenin in Laghu gokshur T. terrestries and Brihat gokshur Pedalium murex by HPTLC method. Int J Pharm Biol Arch 2012;3:1117-20.

60. Shah HJ, Lele SS. Extraction of diosgenin, a bioactive compound from natural source Dioscorea alata var purpurea. J Anal Bioanal Tech 2012;3:1-3.

61. Olayemi JO, Ajaiyeoba EO. Anti-inflammatory studies of yam (Dioscorea esculenta) extract on Wistar rats. Afr J Biotechnol 2007;6:2289.

62. Prasad TN, Sastry KV. A note on the chemical examination of P. murex leaves. Ind Drugs 1989;25:84.

63. Zhang L, Zhang Y, Zhang L, Yang X, Lv Z. Lupeol, a dietary triterpene, inhibited growth, and induced apoptosis through down-regulation of DR3 in SMMC7721 cells. Cancer Investig 2009;27:163-70.

64. Lin Y, Shi R, Wang X, Shen HM. Luteolin, a flavonoid with potential for cancer prevention and therapy. Curr Cancer Drug Targets 2008;8:634-46.

65. Shukla VN, Khanuja SP. Chemical, pharmacological and botanical studies on Pedalium murex. ChemInform 2004;36:26263.

66. Ma CM, Cai SQ, Cui JR, Wang RQ, Tu PF, Hattori M, et al. The cytotoxic activity of ursolic acid derivatives. Eur J Med Chem 2005;40:582-9.

67. Kim SJ, Kim MC, Um JY, Hong SH. The beneficial effect of vanillic acid on ulcerative colitis. Molecules 2010;15:7208-17.

68. Prince PS, Rajakumar S, Dhanasekar K. Protective effects of vanillic acid on electrocardiogram, lipid peroxidation, antioxidants, proinflammatory markers and histopathology in isoproterenol induced cardiotoxic rats. Eur J Pharmacol 2011;668:233-40.

69. Dianat M, Radan M, Badavi M, Sarkaki A. The evaluation of inotropic properties and antidysrhythmic effect of vanillic acid and exercise on Cacl2-induced arrhythmia in young and aged rats. Res J Pharm Biol Chem Sci 2014;5:1545-55.

70. Rao PU. Nutrient composition of some less-familiar oil seeds. Food Chem 1994;50:379-82

71. Sithanantham S, Ballal CR, Jalali SK, Bakthavatsalam N, editors. Biological Control of Insect Pests Using Egg Parasitoids. New Delhi: Springer; 2013.

72. Frawley D, Lad V. The Yoga of Herbs: An Ayurvedic Guide to Herbal Medicine. New Delhi: Motilal Banarsidass Publ.; 1994.

73. Sivapalan SR. Biological and pharmacological studies of Tribulus terrestris Linn a review. Int J Multidiscip Res Dev 2016;3:257-65.

74. Arcasoy HB, Erenmemisoglu A, Tekol Y, Kurucu S, Kartal M. Effect of Tribulus terrestris L. saponin mixture on some smooth muscle preparations: A preliminary study. Boll Chim Farm 1998;137:473-5.

75. Shekhawat D, Batra A. Household Remedies of Keshavraipatan Tehsil in Bundi district, Rajasthan; 2006.

76. Khan FM. Ethno-veterinary medicinal usage of flora of Greater Cholistan desert (Pakistan). Pak Vet J 2009;29:75-80.

77. Vedavathy S, Mrudula V, Sudhakar A. Tribal Medicine of Chittoor District, AP (India). India: Herbal Folklore Research Centre; 1997.

78. Dhiman AK, Archana T. Herbaceous remedial plants of district Haridwar, Uttarakhand, (India). Adv Plant Sci 2009;22:589-94.

79. Upadhyay B, Singh KP, Kumar A. Ethno-veterinary uses and informants consensus factor of medicinal plants of Sariska region, Rajasthan, India. J Ethnopharmacol 2011:133:14-25.

80. Kumar M, Semwal IM, Singh JB, Kanchan. Ethno-medicinal recipes for Leucorrhoea by Nomadic people of Etawah, UP. Vegetos 2008;21:35-8.

81. Balakrishnan V, Prema P, Ravindran KC, Robinson JP. Ethnobotanical studies among villagers from Dharapuram taluk, Tamil Nadu, India. Glob J Pharmacol 2009;3:8-14

82. Upadhyay B, Dhaker AK, Kumar A. Ethnomedicinal and ethnopharmaco-statistical studies of Eastern Rajasthan, India. J Ethnopharmacol 2010;129:64-86.

83. Dipali D, Das MN. Pharmacognostical studies of root and fruit of Gokshura (Pedalium murex Linn.). BMEBR 1995;16:54-65.

84. Katewa SS, Galav PK. Traditional Herbal Medicines from Shekhawati Region of Rajasthan; 2005.

85. Sangeeta D, Sidhu H, Thind SK, Nath R. Therapeutic Effect of Tribulus terrestris (Chota Gokhru, an Ayurvedic Drug) in the management of experimental hyperoxaluria. In: Urolithiasis. Vol. 2. Boston, MA: Springer; 1994. p. 595-596.

86. Sivarajan VV, Balachandran I. Ayurvedic Drugs and Their Plant Sources. New Delhi: Oxford and IBH Publishing; 1994.

87. Joshi VK, Joshi A, Dhiman KS. The ayurvedic pharmacopoeia of India, development and perspectives. J Ethnopharmacol 2017;197:32-8.

88. Srinivasulu B, Rohit KS, Gajanan P, Dhiman KS. Comprehensive review of Krimighna drugs mentioned in the ayurvedic pharmacopoeia of India. Int J Ayurveda Pharm Res 2017;5:688

89. Jayanthy A, Deepak M, Remashree AB. Pharmacognostic characterization and comparison of fruits of Tribulus terrestris L. and Pedalium murex L. Int J Herb Med 2013;1:29-34.

90. Jabbar A, Nazir A, Ansari NI, Javed F, Janjua KM. Effects of Tribulus 
terresteris. Prof Med J 2012;19:843-7.

91. Phillips OA, Mathew KT, Oriowo MA. Antihypertensive and vasodilator effects of methanolic and aqueous extracts of Tribulus terrestris in rats. J Ethnopharmacol 2006;104:351-5.

92. Al-Ali M, Wahbi S, Twaij H, Al-Badr A. Tribulus terrestris: Preliminary study of its diuretic and contractile effects and comparison with Zea mays. J Ethnopharmacol 2003;85:257-60.

93. Singh S, Nair V, Gupta YK. Evaluation of the aphrodisiac activity of Tribulus terrestris Linn. in sexually sluggish male albino rats. J Pharmacol Pharmacother 2012;3:43.

94. Adaikan PG, Gauthaman K, Prasad RN, Ng SC. Proerectile pharmacological effects of Tribulus terrestris extract on the rabbit corpus cavernosum. Ann Acad Med 2000;29:22-6.

95. Rajendar B, Bharavi K, Rao GS, Kishore PV, Kumar PR, Kumar CS, et al. Protective effect of an aphrodisiac herb Tribulus terrestris Linn on cadmium-induced testicular damage. Indian J Pharmacol 2011;43:568.

96. Kavitha P, Ramesh R, Subramanian P. Histopathological changes in Poecilia latipinna male gonad due to Tribulus terrestris administration. In vitro Cell Dev Biol Anim 2012;48:306-12.

97. Adaikan PG, Gauthaman K, Prasad RN. History of herbal medicines with an insight on the pharmacological properties of Tribulus terrestris. Aging Male 2001;4:163-9.

98. Anand R, Patnaik GK, Kulshreshtha DK, Dhawan BN Activity of certain fractions of Tribulus terrestris fruits against experimentally induced urolithiasis in rats. Indian J Exp Biol 1994;32:548-52.

99. Aggarwal A, Tandon S, Kumar Singla S, Tandon C. A novel antilithiatic protein from Tribulus terrestris having cytoprotective potency. Protein Pept Lett 2012;19:812-9.

100.Sangeeta D, Sidhu H, Thind SK, Nath R. Effect of Tribulus terrestris on oxalate metabolism in rats. J Ethnopharmacol 1994;44:61-6.

101.Tilwari A, Shukla NP, Devi PU. Effect of five medicinal plants used in Indian system of medicines on immune function in Wistar rats. Afr J Biotechnol 2011;10:16637-45.

102.Amin AM, Lotfy M, Shafiullah M, Adeghate E. The protective effect of
Tribulus terrestris in diabetes. Ann N Y Acad Sci 2006;1084:391-401. 103.Ayyanna C, Rao GM, Sasikala M, Somasekhar P, Kumar NA, Kumar MV. Absorption enhancement studies of metformin hydrochloride by using Tribulus terrestris plant extract. Int J Pharm Technol 2012;4:4118-25

104.Heidari MR, Mehrabani M, Pardakhty A, Khazaeli P, Zahedi MJ, Yakhchali M, et al. The analgesic effect of Tribulus terrestris extract and comparison of gastric ulcerogenicity of the extract with indomethacine in animal experiments. Ann N Y Acad Sci 2007;1095:418-27.

105.Zhang S, Li H, Yang SJ. Tribulosin protects rat hearts from ischemia/ reperfusion injury. Acta Pharmacol Sin 2010;31:671-8.

106.Deepak M, Dipankar G, Prashanth D, Asha MK, Amit A, Venkataraman BV. Tribulosin and $\beta$-sitosterol-D-glucoside, the anthelmintic principles of Tribulus terrestris. Phytomedicine 2002;9:753-6.

107.Zhang JD, Xu Z, Cao YB, Chen HS, Yan L, An MM, et al. Antifungal activities and action mechanisms of compounds from Tribulus terrestris L. J Ethnopharmacol 2006;103:76-84.

108. Shelke TT, Kothai R, Adkar PP, Bhaskar VH, Juvale KC, Kamble BB, et al. Nephroprotective activity of ethanolic extract of dried fruits of Pedalium murex Linn. J Cell Tissue Res 2009;9:1687.

109.Patel MK, Mandavia DR, Patel TK, Barvaliya MJ, Tripathi CB. Evaluation of anti-inflammatory, analgesic, and antipyretic effects of ethanolic extract of Pedalium murex Linn. fruits. Afr J Tradit Complement Altern Med 2013;10:94-100.

110.Mozhi MT, Mulaicharam AR, Murugesh S. Phytochemical and pharmacognostical studies on Pedalium murex Linn. Int J Res Ayurveda Pharm 2011;2:253-8.

111. Arockiasamy S, Kuppuswamy VR. Antiproliferative activity of methanolic fruit extract of Pedalium murex Linn against lung cancer cell line A549. J Pharm Res 2012;5:2861-6.

112. Srinivas P, Venkateshwarulu L, Kumar AC. Antioxidant activity of Pedalium murex fruits in carbon tetra chloride-induced hepatopathy in rats. Int J Pharm Bio Sci 2011;2:622-8. 